\title{
Glucagon-Like Peptide-1 Receptor Agonist Reduces di(2-ethylhexyl) Phthalate-Induced Atherosclerotic Processes in Vascular Smooth Muscle Cells
}

\author{
Jin Hee KIM ${ }^{1}$ \\ ${ }^{1}$ Department of Internal Medicine, Seoul National University Bundang Hospital, Seoul National \\ University College of Medicine, Seongnam, South Korea
}

Received April 4, 2020

Accepted September 7, 2020

Epub Ahead of Print November 2, 2020

\begin{abstract}
Summary
Glucagon-like peptide-1 receptor (GLP1R) agonist is an incretin hormone and regulates glucose metabolism. However, phthalates, known as endocrine disruptors, can interfere with hormone homeostasis. In the present study, we aimed to estimate the impact of GLP1R agonist on di(2-ethylhexyl) phthalate (DEHP)-induced atherosclerosis. For this purpose, the effects of GLP1R agonist on various atherogenesis-related cellular processes and pathways were assessed in vascular smooth muscle cells (VSMCs). DEHP-induced cell proliferation and migration were significantly decreased by GLP1R agonist in VSMCs. Protein levels of matrix metalloproteinase (MMP)-2 and MMP-9 were significantly decreased in cells exposed to GLP1R agonist, compared with DEHP-treated cells. Expression levels of intercellular adhesion molecule 1 and vascular cell adhesion molecule 1 were also reduced in GLP1R agonist-treated cells. Similarly, DEHP-associated phosphorylation of protein kinase $B$ and extracellular signal-regulated kinase $1 / 2$ was decreased in GLP1R agonist-treated cells, compared with DEHP-treated cells. Our findings suggest that treatment with GLP1R agonist counteracts the activation of pathways related to atherosclerosis.
\end{abstract}

\section{Key words}

Glucagon-like peptide-1 receptor (GLP1R) agonist • di (2-ethyIhexyl) phthalate (DEHP) • Vascular smooth muscle cells (VSMCs)

- Atherosclerosis

\section{Corresponding author}

Jin Hee Kim, Department of Internal Medicine, Seoul National University College of Medicine, Seoul National University Bundang Hospital, 82, Gumi-ro 173 Beon-gil, Bundang-gu, Seongnam-city, South Korea. E-mail: kjin014@gmail.com

\section{Introduction}

Cardiovascular disease (CVD) is a major cause of death and disability in diabetes (Laakso et al. 1999, Angeli FS and Shannon RP 2014). Atherosclerotic CVD includes myocardial infarction, peripheral arterial disease, and stroke and is a common cause of death in $80 \%$ of the patients with type 2 diabetes (Martín-Timón et al. 2014). Atherosclerosis accompanied by vascular smooth muscle cell (VSMC) dysfunction is correlated to CVD risks (Abdul-Ghani et al. 2017, Doran et al. 2008). VSMCs play a pivotal role in vascular morphogenesis and regulation of vascular homeostasis (Ross 1995). Abnormal VSMC phenotype is a characteristic of vascular disorders, including atherosclerosis. Aberrant VSMCs in atherosclerosis promote the induction of highly proliferative VSMC phenotypes and plaque formation in the vessel environment (Ross 1995, Martin et al. 2016).

Di(2-ethylhexyl) phthalate (DEHP) is one of the most common phthalates acting as environmental endocrine disruptors and is widely used as a plasticizer to make plastic flexible (Hauser R 2005). Many studies show that DEHP affects the human reproductive system, the development of certain types of cancer, hepatotoxicity, and atherosclerosis-related CVD (Latini et al. 2006, Zhu et al. 2010, Ghosh et al. 2010). In addition, DEHP was shown to be associated with atherosclerosis-related CVD complications by promoting oxidative stress and increasing the expression of proinflammatory mediators (Zhao et al. 2016).

Glucagon-like peptide-1 receptor (GLP1R) 
agonists have emerged as effective treatments for diabetes and improve insulin sensitivity in liver by reducing macrophage infiltration and inhibiting inflammation (Chai et al. 2012, Gao et al. 2007, Lee et al. 2012). GLP1R agonist may also impact biological functions in CVD. Recently, the clinical trial Liraglutide Effect and Action in Diabetes: Evaluation of Cardiovascular Outcome Results (LEADER) showed a striking reduction in the relative risk of cardiovascular (CV) death and all-cause mortality in patients with type 2 diabetes at high CV risk on liraglutide therapy compared with patients administered with placebo (Marso et al. 2016). In a randomized clinical trial, treatment with $3.0 \mathrm{mg}$ of liraglutide decreased the energy intake and weight loss in patients with type 2 diabetes (Pi-Sunyer et al. 2015, Lim et al. 2018).

In this study, for the first time, the ability of GLP1R agonist to alleviate vascular complications was determined by investigating its effect on atherosclerosisassociated processes in DEHP-treated VSMCs.

\section{Methods}

\section{Cell culture}

Rat aortic smooth muscle cells (RAoSMCs) were purchased from the American Type Culture Collection (ATCC, Manassas, VA, USA). Cells were maintained in Dulbecco's modified Eagles's medium (DMEM) with $10 \%$ fetal bovine serum (FBS; HyClone Laboratories, Logan, UT, USA) in a humidified atmosphere of $5 \% \mathrm{CO}_{2}$ and $95 \%$ air at $37{ }^{\circ} \mathrm{C}$. The medium was replaced every two days. Prior to the experiments, cells were plated in 96-well plates at a density of $\sim 1.5 \times 10^{4}$ cells per well (cell proliferation assay) or in six-well plates at $5 \times 10^{6}$ cells per well (all other assays). For the experiments, the cells were incubated with the agents for $24 \mathrm{~h}$ at $37{ }^{\circ} \mathrm{C}$. In each experiment, treatments were performed in triplicate.

\section{Cell viability assay}

Cells were cultured to $80-90 \%$ confluence and then starved in serum-free DMEM for $24 \mathrm{~h}$. The medium was then replaced with fresh medium containing different concentrations of GLP1R agonist (Sigma-Aldrich, St. Louis, MO, USA) in the presence or absence of DEHP (Sigma-Aldrich). Cell viability was analyzed using the 3(4,5-dimethylthiazol-2-yl)-5-(3-carboxymethoxyphenyl)2-(4-sulfophenyl)-2H-tetrazolium (MTS) cell proliferation assay (CellTiter 96®AQueous Cell Proliferation
Assay kit; Promega Corporation, Madison, WI, USA), according to the manufacturer's protocol. Briefly, cells were cultured for $24 \mathrm{~h}$, and $20 \mu \mathrm{l}$ of MTS solution was added to $100 \mu \mathrm{l}$ of culture medium. Cells were subsequently incubated at $37{ }^{\circ} \mathrm{C}$ for $4 \mathrm{~h}$, and the absorbance was measured at $490 \mathrm{~nm}$ using a microplate reader.

\section{Wound healing migration assay}

Cells were grown to $90 \%$ confluence and then subjected to scratching using a sterile pipette tip. Medium was replaced with fresh medium containing different concentrations of GLP-1R agonist in the presence or absence of DEHP. The scratch wound was allowed to heal for $24 \mathrm{~h}$ in the presence or absence of the indicated chemicals. Phase-contrast microscopy images (Optika, Ponteranica, Italy) of each sample were captured at 0 and $24 \mathrm{~h}$, and VSMC ability to migrate was evaluated by measuring the area of the scratch wound at both time points using ImageJ software (version 1.29x, National Institutes of Health, Bethesda, MD, USA).

\section{Western blot analysis}

Cells $\left(1 \times 10^{6} / \mathrm{ml}\right)$ were resuspended in a lysis buffer (Cell Signaling Technology, Inc., Danvers, MA, USA) containing a protease inhibitor cocktail (cOmplete $^{\mathrm{TM}}$ Mini Protease Inhibitor Tablet; Roche Diagnostics GmbH, Mannheim, Germany). Protein concentration was measured in the supernatant using a Pierce BCA Protein Assay Kit (cat. no. 23225; Thermo Fisher Scientific, Inc., Waltham, MA, USA). In total, $40 \mu \mathrm{g}$ of protein was loaded per lane, separated by $10 \%$ SDS-PAGE, and transferred onto nitrocellulose membranes (Thermo Fisher Scientific, Inc.). Membranes were blocked for $2 \mathrm{~h}$ at room temperature with $5 \%$ skimmed milk in Tris-buffered saline-Tween-20 (TBST; $20 \mathrm{mM}$ Tris, $500 \mathrm{nM} \mathrm{NaCl}, 0.1 \%$ Tween-20), and then incubated with primary antibodies against matrix metalloproteinase (MMP)-2 (1:1000; Cell Signaling Technology, Boston, MA, USA), MMP-9 (1:1000; Cell Signaling Technology), intercellular adhesion molecule (ICAM)-1 (1:1000; Cell Signaling Technology), vascular cell adhesion molecule (VCAM)-1 (1:1000; Cell Signaling Technology), phospho-Akt (1:1000; Cell Signaling Technology), phospho-ERK1/2 (1:1000; Cell Signaling Technology), phospho-p38 (1:1000; Cell Signaling Technology), phospho-JNK (1:1000; Cell Signaling Technology), and $\beta$-actin (1:5000; Santa Cruz Biotechnology, Dallas, TX, USA) overnight at $4{ }^{\circ} \mathrm{C}$. 
Following three washes with TBST, membranes were incubated with secondary horseradish peroxidase-conjugated anti-IgG antibodies (1:5000; Thermo Fisher Scientific, Inc.) for $2 \mathrm{~h}$ at room temperature and visualized using a Pierce enhanced chemiluminescence substrate (Thermo Fisher Scientific, Inc.). Densitometric quantification of the protein bands was performed using Image J software (version 1.29x, National Institutes of Health).

\section{Statistical analysis}

Quantitative data are presented as mean \pm SEM. Differences between mean values were compared statistically using the two-tailed Student's t-test or oneway analysis of variance followed by Tukey's post hoc comparison. Statistical analysis was performed using SPSS windows software 22.0 (IBM Corp., Armonk, NY, USA). A P value of $<0.05$ was considered statistically significant. All experiments were performed at least three times.

\section{Results}

GLP1R agonist reduces DEHP-induced cell proliferation in VSMCS

To determine whether GLP1R agonist affects VSMC proliferation, we performed an MTS cell proliferation assay. DEHP-induced proliferative effects were significantly decreased by GLP1R agonist at a concentration of $100 \mathrm{nM}$ after $24 \mathrm{~h}$ and at $50 \mathrm{nM}$ and $100 \mathrm{nM}$ after $48 \mathrm{~h}$ (Fig. 1). Subsequent experiments were performed using a cellular concentration of $100 \mathrm{nM}$ of GLP1R agonist. In the next experiments, we focused our attention on further defining the therapeutic potential of GLP1R agonist.

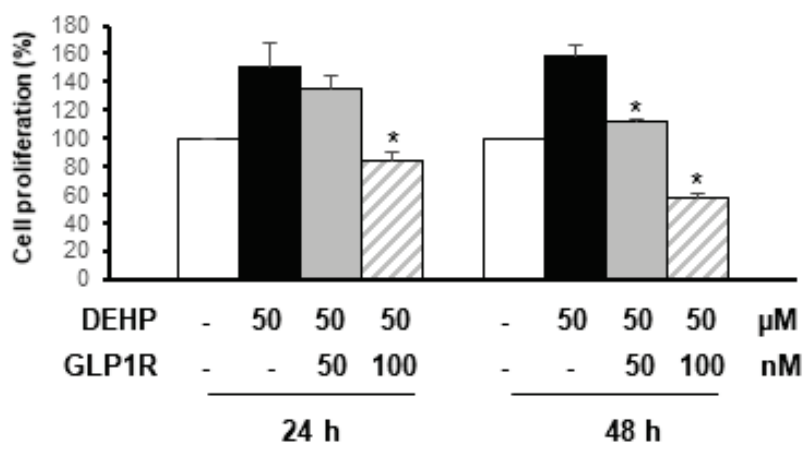

Fig. 1. GLP1R agonist reduces cell proliferation. An MTS proliferation assay was performed to determine VSMC viability. VSMCs were exposed to the indicated concentrations of GLP1R agonist for $24 \mathrm{~h}$, followed by treatment with DEHP $(50 \mu \mathrm{M})$ (means $\pm \mathrm{SEM} ; * P<0.05$ ).
GLPIR agonist reduces DEHP-induced cell migration in VSMCs

A wound-healing migration assay was performed to determine the effects of GLP1R agonist on DEHP-stimulated VSMC migration. DEHP-induced VSMC motility was significantly reduced by GLP1R agonist after $24 \mathrm{~h}$, as compared with DEHP-treated cells in the absence of GLP1R agonist (Fig. 2).
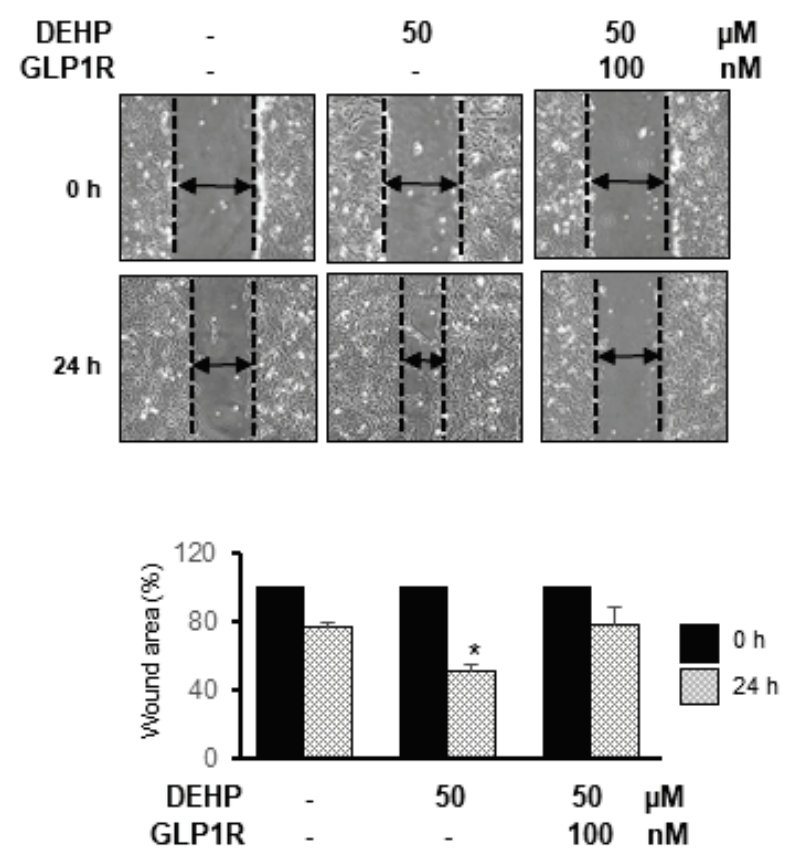

Fig. 2. GLP1R agonist reduces cell migration. Quantification of the wound area. The effect of a 24-h treatment with GLP1R agonist on the migration of VSMCs was determined using a scratch wound healing migration assay. Each experiment was performed in triplicate (means $\pm \mathrm{SEM} ; * P<0.05$ ).

GLP1R agonist reduces DEHP-induced expression of inflammation and adhesion molecules in VSMCs

Expression of MMPs is increased in VSMCs during the development of atherosclerosis. The initiation of atherosclerosis involves the up-regulation of molecules such as ICAM-1 and VCAM-1 (Senior et al. 1991, Newby and Zaltsman 2000). MMP-2 and MMP-9 protein expression levels were measured by western blot. MMP-9 expression was markedly decreased following exposure to $100 \mathrm{nM}$ of GLP1R agonist for $24 \mathrm{~h}$ and $48 \mathrm{~h}$ compared with that in DEHP-treated cells in the absence of GLP1R $(\mathrm{P}<0.05)$. However, MMP-2 expression was markedly decreased following exposure to $100 \mathrm{nM}$ of GLP1R agonist for $24 \mathrm{~h}$ but not $48 \mathrm{~h}$ compared with that in DEHP-treated cells in the absence of GLP1R agonist (Fig. 3). 

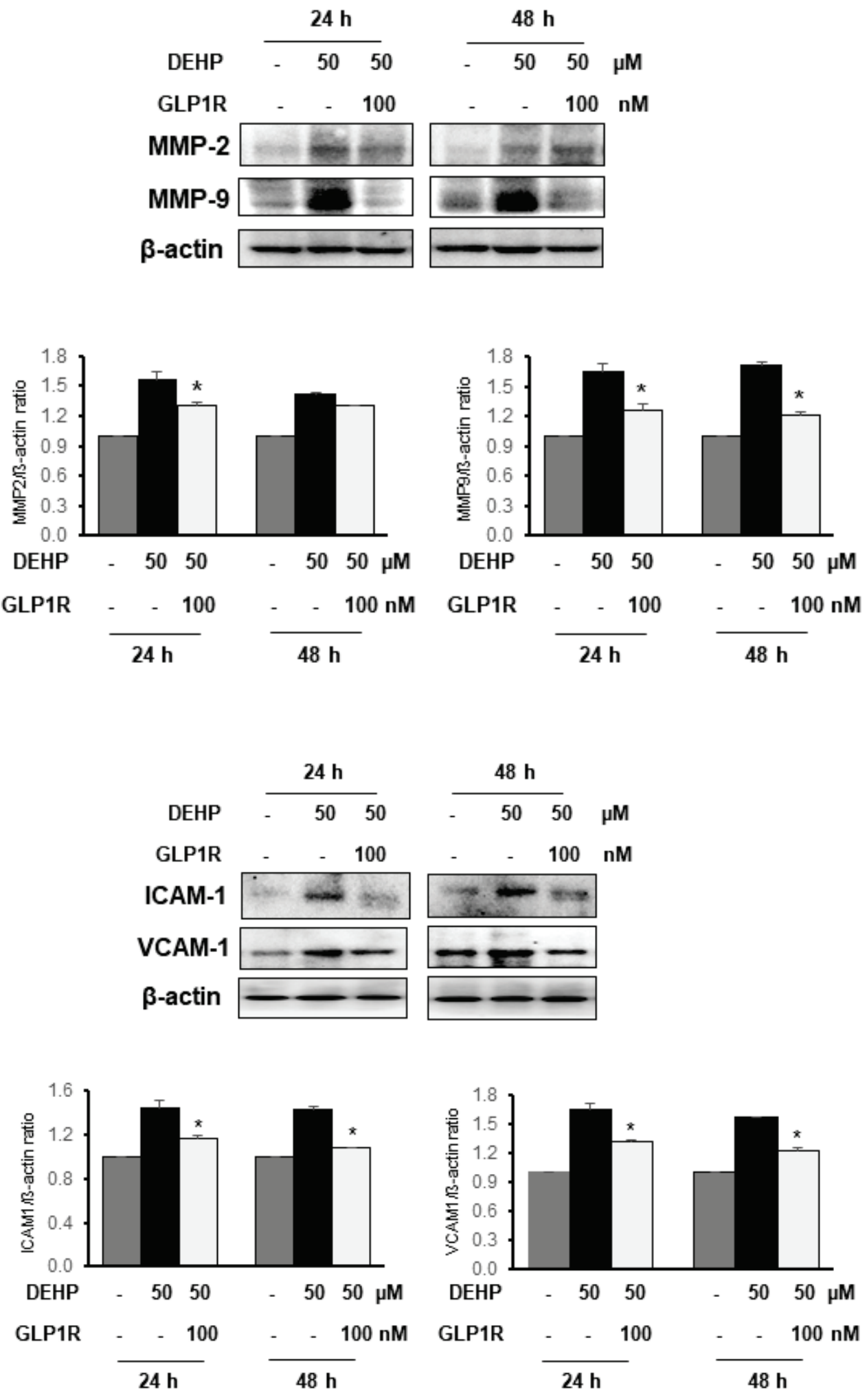

Fig. 3. Effect of GLP1R agonist on the expression of inflammation factors in VSMCs. DEHP-induced MMP-2 and MMP-9 expression was markedly reduced in the presence of GLP1R agonist in VSMCs when compared with DEHP-stimulated cells in the absence of GLP1R agonist (means $\pm \mathrm{SEM} ; * P<0.05$ ).

Fig. 4. Effect of GLP1R agonist on the expression of adhesion molecules in VSMCs. DEHP-induced ICAM-1 and VCAM-1 expression was markedly reduced in the presence of GLP1R agonist in VSMCs when compared with DEHP-stimulated cells in the absence of GLP1R agonist (means $\pm \mathrm{SEM} ; * P<0.05$ ).
ICAM-1 and VCAM-1 protein expression levels were measured by western blot. DEHP-induced ICAM-1 and VCAM-1 expression was strongly suppressed in the presence of $100 \mathrm{nM}$ of GLP1R agonist in VSMCs compared with that in DEHP-treated cells in the absence of GLP1R agonist (Fig. 4).
GLP1R agonist reduces DEHP-induced activation of the Akt and ERK1/2 signaling pathways in VSMCs

To identify the signaling pathways involved in the effects of the GLP1R agonist, we examined the phosphorylation of Akt and ERK1/2 by western blot. As shown in Fig. 5, the treatment with $100 \mathrm{nM}$ GLP1R 

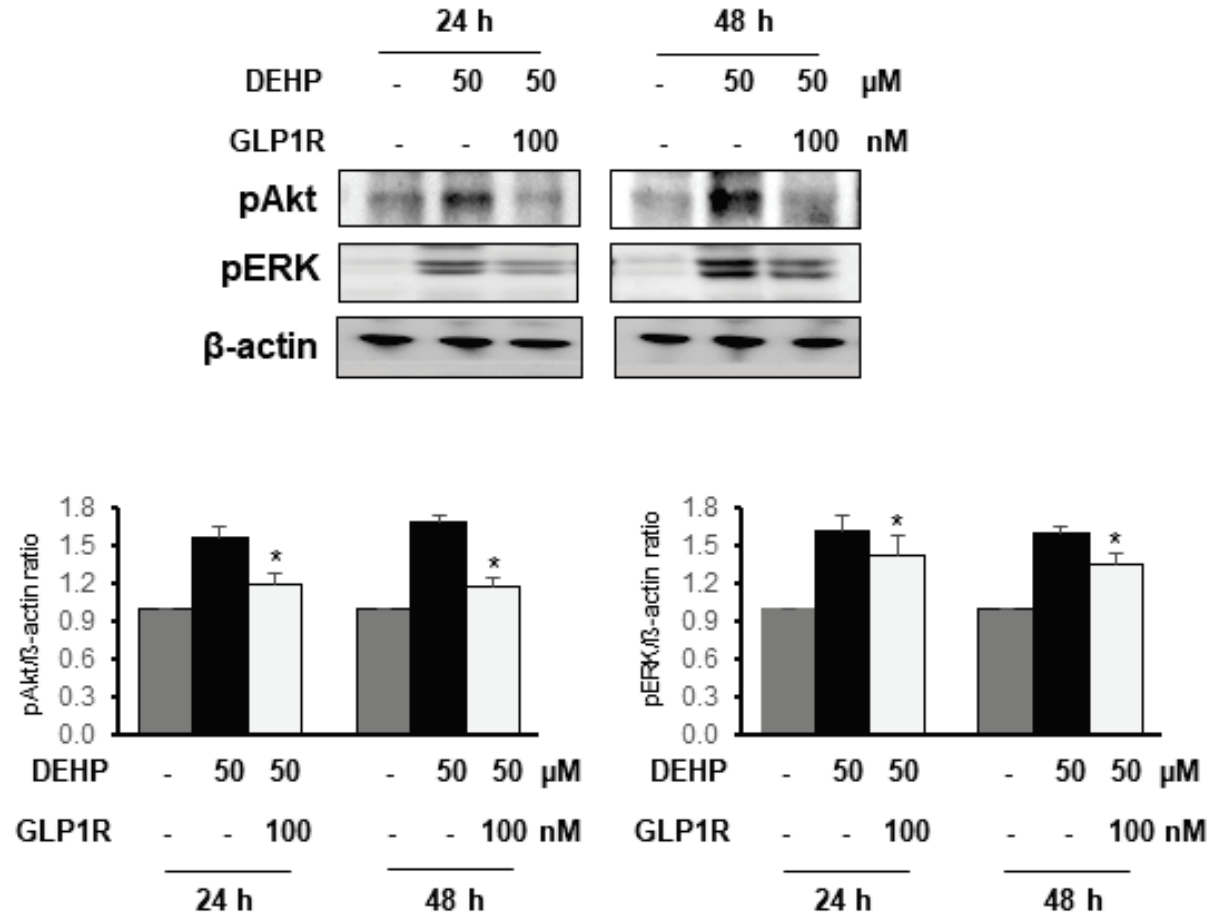

agonist significantly suppressed DEHP-induced phosphorylation of Akt and ERK1/2 in VSMCs. The protein levels of p-JNK and p-p38 were not affected by the above treatments (data not shown).

\section{Discussion}

In this study, we investigated whether GLP1R agonist exerts suppressive effects on DEHP-treated VSMCs. Although the molecular mechanisms underlying the impact of DEHP are not fully understood, our data show that GLP1R agonist downregulates DEHP-induced expression of the inflammatory markers MMP-2 and MMP-9, as well as the adhesion molecules ICAM-1 and VCAM-1, in VSMCs. Moreover, the results of this study show that the inhibition of factors involved in inflammatory and atherosclerotic processes following GLP1R agonist therapy occur via the Akt and ERK1/2 pathways. This is the first study showing that GLP1R agonist is effective against DEHP-induced vascular complications.

DEHP has been associated with breast cancer, obesity, and atherosclerosis (Güven et al. 2005, Lin et al. 2011). Moreover, DEHP was linked to atherosclerosisrelated CVD complications through the induction of inflammatory cytokines (Zhao et al. 2016). Atherosclerosis is associated with chronic inflammatory disorders involving monocytes, macrophages, endothelial cells, and smooth muscle cells (Ilhan and Kalkanli 2015).
Fig. 5. GLP1R agonist reduces the phosphorylation of Akt and ERK1/2 in VSMCs. DEHP-induced Akt and ERK1/2 phosphorylation was markedly reduced in the presence of GLP1R agonist in VSMCs when compared with DEHP-stimulated cells in the absence of GLP1R agonist (means $\pm \mathrm{SEM} ; * P<0.05$ ).
Increased proliferation and migration of VSMCs are involved in the formation of vascular diseases and finally lead to the development of atherosclerosis (Jawien et al. 1992). DEHP-induced proliferation of VSMCs involves the onset of vascular injury and atherosclerosis (Zhao et al. 2016). A recent study showed that GLP1 treatment effectively inhibited the proliferation of VSMCs via the AMPK signaling pathway (Teruo et al. 2017). In the present study, we found that $100 \mathrm{nM}$ of GLP1R agonist inhibited the proliferation of VSMCs in response to DEHP.

Atherosclerosis is a major cause of the increased expression of inflammation and adhesion molecules in VSMCs following injury (Rolfe et al. 2000). The expression of MMPs, a family of zinc-dependent proteolytic enzymes, in VSMCs is associated with the degradation of connective tissue proteins and increased risk of developing atherosclerotic plaques (Newby 2005). Also, MMPs are critical for the development of arterial lesions through the regulation of proliferation and migration of smooth muscle cells (Cho and Reidy 2002). The expression of ICAM-1 and VCAM-1 on intimal smooth muscle cells is promoted in the atherosclerotic vascular wall (Jang et al. 1994). Several studies have investigated that VSMCs increased the ICAM-1 and VCAM-1 expression in atherosclerosis (Newby and Zaltsman 2000, Senior et al. 1991). Notably, GLP1 induced advantageous anti-inflammatory effects on human umbilical vein endothelial cells, human vascular 
endothelial cells, and vascular diseases, including atherosclerosis and CVDs, in vivo and in vitro (Lee and Jun 2016). Our results showed that the GLP1R agonist decreased the expression of MMP-2, MMP-9, ICAM-1, and VCAM-1, indicating that decreased inflammation may be associated with the improvement of atherosclerosis. Thus, the GLP1R agonist seems to exhibit anti-inflammatory effects, which in turn may be beneficial in the prevention of atherosclerosis.

Akt and MAPK signaling pathways play a crucial role in the regulation of several diseases. Moreover, Akt and MAP/ERK1/2 signaling pathways play an important role in VSMC proliferation and migration (Rudijanto 2007, Seo et al. 2013, Qin et al. 2014). Previous studies have reported that GLP1R protects cardiomyocytes, endothelial cells, and VSMCs via Akt and ERK1/2 signaling cascades (Campbell and Trimble 2005, Wang 2002, Li et al. 2013, Igarashi et al. 2007). In view of these data, we investigated whether GLP1R agonist affected Akt and ERK1/2 activation.
GLP1R agonist significantly reduced DEHP-induced Akt and ERK1/2 phosphorylation in VSMCs, suggesting the therapeutic applicability of GLP1R agonist in the prevention of atherosclerosis. Consequently, GLP1R agonist could be a more effective therapeutic agent against the DEHP-induced vascular complications.

In conclusion, the present study expands our understanding of the effects of the GLP1R agonist in VSMCs, revealing its potential for preventing the development of atherosclerosis. Thus, other or chemically modified GLP1R agonists may represent promising candidates for the treatment of atherosclerosis. Our study highlights the protective effect of the GLP1R agonist that significantly decreased cell viability and migration of DEHP-stimulated VSMCs through the inhibition of tissue remodeling and adhesion factors and the atherosclerosisassociated Akt and ERK1/2 pathways.

\section{Conflict of Interest}

There is no conflict of interest.

\section{References}

ABDUL-GHANI M, DEFRONZO RA, DEL PRATO S, CHILTON R, SINGH R, RYDER R: Cardiovascular disease and type 2 diabetes: has the dawn of a new era arrived? Diabetes Care 40: 813-820, 2017. https://doi.org/10.2337/dc16-2736

ANGELI FS, SHANNON RP: Beyond glycemic control: cardiovascular effects of incretin-based therapies. Front Horm Res 43: 144-157, 2014.

CAMPBELL M, TRIMBLE ER: Modification of PI3K- and MAPK-dependent chemotaxis in aortic vascular smooth muscle cells by protein kinase CbetaII. Circ Res 96: 197-206, 2005. https://doi.org/10.1161/01.RES.0000152966.88353.9d

CHAI W, DONG Z, WANG N, TAO L, CAOW, LIU Z: Glucagon-like peptide 1 recruits microvasculature and increases glucose use in muscle via a nitric oxide-dependent mechanism. Diabetes 61: 888 896, 2012. https://doi.org/10.2337/db11-1073

CHO A, REIDY MA: Matrix metalloproteinase-9 is necessary for the regulation of smooth muscle cell replication and $\begin{array}{llllll}\text { migration after arterial injury. Circ Res 91: } & \text { 845-851, } 2002 .\end{array}$ https://doi.org/10.1161/01.RES.0000040420.17366.2E

DEACON CF, AHREN B: Physiology of incretins in health and disease. Rev Diabet Stud 8: 293e306, 2011. https://doi.org/10.1900/RDS.2011.8.293

DORAN AC, MELLER N, MCNAMARA CA: Role of smooth muscle cells in the initiation and early progression of $\begin{array}{lllllll}\text { atherosclerosis. } & \text { Arterioscler } & \text { Thromb } & \text { Vasc } & \text { Biol } & \text { 28: } & 812-819,\end{array}$ https://doi.org/10.1161/ATVBAHA.107.159327

FAVARO E, GRANATA R, MICELI I, BARAGLI A, SETTANNI F, CAVALLO PP, GHIGO E, CAMUSSI G, ZANONE MM: The ghrelin gene products and exendin-4 promote survival of human pancreatic islet endothelial cells in hyperglycaemic conditions, through phosphoinositide 3-kinase/AKT, extracellular signalrelated kinase (ERK)1/2 and cAMP/protein kinase A (PKA) signalling pathways. Diabetologia 55: 1058-1070, 2012. https://doi.org/10.1007/s00125-011-2423-y

GAO H, WANG X, ZHANG Z, YANG Y, YANG J, LI Z, NING G: GLP1 amplifies insulin signaling by up-regulation of IR $\beta$, IRS-1 and Glut4 in 3T3-L1 adipocytes. Endocrine 32: 90-95, 2007. https://doi.org/10.1007/s12020007-9011-4 
GHOSH J, DAS J, MANNA P, SIL PC: Hepatotoxicity of di-(2-ethylhexyl) phthalate is attributed to calcium aggravation, ROS-mediated mitochondrial depolarization, and ERK/NF-kB pathway activation. Free Radic Biol Med 49: 1779-1791, 2010. https://doi.org/10.1016/j.freeradbiomed.2010.09.011

GÜVEN A, CINAZ P, BIDECI A: Is premature adrenarche a risk factor for atherogenesis? Pediatr Int 47: 20-25, 2005. https://doi.org/10.1111/j.1442-200x.2004.02006.x

HAUSER R, CALAFAT AM: Phthalates and human health. Occup Environ Med 62: 806-818, 2005. https://doi.org/10.1136/oem.2004.017590

IGARASHI M, HIRATA A, YAMAGUCHI H, SUGAE N, KADOMOTO-ANTSUKI Y, NOZAKI H, JIMBU Y, TOMINAGA M: Characterization of activation of MAP kinase superfamily in vasculature from diabetic rats. J Atheroscler Thromb 14: 235-244, 2007. https://doi.org/10.5551/jat.E514

ILHAN F, KALKANLI TS: Atherosclerosis and the role of immune cells. World J Clin Cases 3: 345-352, 2015. https://doi.org/10.12998/wjcc.v3.i4.345

JANG Y, LINCOFF M, PLOW EF, TOPOL EJ: Cell adhesion molecules in coronary artery disease. J Am Cardiol 24: 1591-1601, 1994. https://doi.org/10.1016/0735-1097(94)90162-7

JAWIEN A, BOWEN-POPE DF, LINDER V, SCHWARTZ SM, CLOWES AW: Platelet-derived growth factor promotes smooth muscle migration and intimal thickening in a rat model of balloon angioplasty. J Clin Invest 89: 507-511, 1992. https://doi.org/10.1172/JCI115613

LAAKSO M: Hyperglycemia and cardiovascular disease in type 2 diabetes. Diabetes 48: 937-942, 1999. https://doi.org/10.2337/diabetes.48.5.937

LATINI G, Del VECCHIO A, MASSARO M, VERROTTI A, De FELICE C: Phthalate exposure and male infertility. Toxicology 226: 90-98, 2006. https://doi.org/10.1016/j.tox.2006.07.011

LEE YS, JUN HS: Anti-inflammatory effects of GLP-1-based therapies beyond glucose control. Mediators Inflamm 2016: 3094642, 2016. https://doi.org/10.1155/2016/3094642

LEE YS, PARK MS, CHOUNG JS, KIM SS, OH HH, CHOI CS, HA SY, KANG Y, KIM Y, JUN HS: Glucagon-like peptide-1 inhibits adipose tissue macrophage infiltration and inflam $\neg$ mation in an obese mouse model of diabetes. Diabetologia 55: 2456 2468, 2012. https://doi.org/10.1007/s00125-012-2592-3

LI H, PENG W, ZHUANG J, LU Y, JIAN W, WEI Y, LI W, XU Y: Vaspin attenuates high glucose-induced vascular smooth muscle cells proliferation and chemokinesis by inhibiting the MAPK, PI3K/Akt, and NF-kappa B signaling pathways. Atherosclerosis 228: 61-68, 2013. https://doi.org/10.1016/j.atherosclerosis.2013.02.013

LIM S, KIM KM, NAUCK MA: Glucagon-like peptide-1 receptor agonists and cardiovascular events: class effects $\begin{array}{llllll}\text { versus individual patterns. Trends Endocrinol Metab 29: } 238-248, & \end{array}$ https://doi.org/10.1016/j.tem.2018.01.011

LIN S, KU HY, SU PH, CHEN JW, HUANG PC, ANGERER J, WANG SL: Phthalate exposure in pregnant women and their children in central Taiwan. Chemosphere 82: 947-955, 2011. https://doi.org/10.1016/j.chemosphere.2010.10.073

MARSO SP, DANIELS GH, BROWN-FRANDSEN K, KRISTENSEN P, MANN JF, NAUCK MA, NISSEN SE, POCOCK S, POULTER NR, RAVN LS, STEINBERG WM, STOCKNER M, ZINMAN B, BERGENSTAL RM, BUSE JB; LEADER STEERING COMMITTEE; LEADER TRIAL INVESTIGATORS: Liraglutide and cardiovascular outcomes in type 2 diabetes. $\mathrm{N}$ Engl $\mathrm{J}$ Med 375: 311-322, 2016. https://doi.org/10.1056/NEJMoa1603827

MARTIN R BENNETT, SANJAY SINHA, GARY K OWENS: Vascular smooth muscle cells in atherosclerosis. Circ Res 118: 692-702, 2016. https://doi.org/10.1161/CIRCRESAHA.115.306361

MARTÍN-TIMÓN I, SEVILLANO-COLLANTES C, SEGURA-GALINDO A, DEL DAÑIZO-GÓMEZ FJ: Type 2 diabetes and cardiovascular disease: Have all risk factors the same strength? World J Diabetes 5: 444-470, 2014. https://doi.org/10.4239/wjd.v5.i4.444

NEWBY AC: Dual role of matrix metalloproteinases (Matrixins) in intimal thickening of atherosclerotic plaque rupture. Physiol Rev 85: 1-31, 2005. https://doi.org/10.1152/physrev.00048.2003

NEWBY AC, ZALTSMAN AB: Molecular mechanisms in intimal hyperplasia. J Pathol 190: 300-309, 2000. https://doi.org/10.1002/(SICI)1096-9896(200002)190:3<300::AID-PATH596>3.0.CO;2-I 
PI-SUNYER X, ASTRUP A, FUJIONKA, GREENWAY, HALPERN A, KREMPF M, LAU DC, LE ROUX CW, VIOLANTE ORTIZ R, JENSEN CB, WILDING JP, SCALE OBESITY AND PREDIABETES NN 8022-1839 STUDY GROUP: A randomized, controlled trial of $3.0 \mathrm{mg}$ of liraglutide in weight management. N Engl J Med 373: 11-22, 2015. https://doi.org/10.1056/NEJMoa1411892

QIN L, YANG YB, YANG YX, GONG YZ, LI XL, LI GY, LUO HD, XIE XJ, ZHENG XL, LIAO DF: Inhibition of smooth muscle cell proliferation by ezetimibe via the cyclin D1-MAPK pathway. J Pharmacol Sci 125: 283-291, 2014. https://doi.org/10.1254/jphs.13239FP

ROLFE BE, MUDDIMAN JD, SMITH NJ, CAMPBELL GR, CAMBELL JH: ICAM-1 expression by vascular smooth muscle cells is phenotype-dependent. Atherosclerosis 149: 99-110, 2000. https://doi.org/10.1016/S00219150(99)00322-6

ROSS R: Cell biology of atherosclerosis. Annu Rev Physiol 57: 791-804, 1995. https://doi.org/10.1146/annurev.ph.57.030195.004043

RUDIJANTO A: The role of vascular smooth muscle cells on the pathogenesis of atherosclerosis. Acta Med Indones 39: 86-93, 2007.

SANDOVAL DA, D'ALESSIO DA: Physiology of proglucagon peptides: role of glucagon and GLP-1 in health and disease. Physiol Rev 95: 513e48, 2015. https://doi.org/10.1152/physrev.00013.2014

SENIOR RM, GRIFFIN GL, FLISZAR CJ, SHAPIRO SD, GOLDERG GL, WELGUS HG: Human 92- and 72-kilodalton type IV collagenases are elastases. J Biol Chem 266: 7870-7875, 1991.

SEO KW, LEE SJ, KIM YH, BAE JU, PARK SY, BAE SS, KIM CD: Mechanical stretch increases MMP-2 production in vascular smooth muscle cells via activation of PDGFR-/Akt signaling pathway. PLoS ONE 8: e70437, 2013. https://doi.org/10.1371/journal.pone.0070437

TERUO JOJIMA, KOHSUKE UCHIDA, KAZUMI AKIMOTO, TAKANORI TOMOTSUNE, KAZUNORI YANAGI, TOSHIE LIJIMA, KUNIHIRO SUZUKI, KIKUO KASAI, YOSHIMASA ASO: Liraglutide, a GLP-1 receptor agonist, inhibits vascular smooth muscle cell proliferation by enhancing AMP-activated protein kinase and cell cycle regulation, and delays atherosclerosis in ApoE deficient mice. Atherosclerosis 261: 44-51:2017. https://doi.org/10.1016/j.atherosclerosis.2017.04.001

WENTE W, EFANOV AM, BRENNER M, KHARITONENKOV A, KÖSTER A, SANDUSKY GE, SEWING S, TREINIES L, ZITZER H, GROMADA J: Fibroblast growth factor-21 improves pancreatic beta-cell function and survival by activation of extracellular signal-regulated kinase 1/2 and Akt signaling pathways. Diabetes 55: 2470-2478, 2006. https://doi.org/10.2337/db05-1435

WANG W, PRINCE CZ, MOU Y, POLLMAN MJ: Notch3 signaling in vascular smooth muscle cells induces c-FLIP expression via ERK/MAPK activation. Resistance to Fas ligand-induced apoptosis. J Biol Chem 277: 21723-21729, 2002. https://doi.org/10.1074/jbc.M202224200

ZHU H, ZHENG J, XIAO X, ZHENG S, DONG K, LIU J, WANG Y: Environmental endocrine disruptors promote invasion and metastasis of SK-N-SH human neuroblastoma cells. Oncol Rep 23: 129-139, 2010. https://doi.org/10.3892/or 00000614

ZHAO JF, HSIAO SH, HSU MH, PAO KC, KOU YR, SHYUE SK, LEE TS: Di-(2-ethylhexyl) phthalate accelerates atherosclerosis in apolipoprotein E-deficient mice. Arch Toxicol 90: 181-190, 2016. https://doi.org/10.1007/s00204-014-1377-5 